\title{
CrimRxiv
}

\section{Mapping the risk terrain for crime using machine learning}

Andrew Wheeler, Wouter Steenbeek

Published on: Jan 17, 2020

DOI: $10.21428 / c b 6 a b 371.9 d 5 f 4 a 40$

License: Creative Commons Attribution 4.0 International License (CC-BY 4.0). 
